\title{
Corruption, Political Instability and Economic Development in the Economic Community of West African States (ECOWAS): Is There a Causal Relationship?
}

Nurudeen Abu', Mohd Zaini Abd Karim', Mukhriz Izraf Azman Aziz²

ABSTRACT Despite the abundant research on economic development, corruption and political instability, little research has attempted to examine whether there is a causal relationship among them. This paper examines the causal relationship among corruption, political instability and economic development in the ECOWAS using the Granger causality test within a multivariate cointegration and error-correction framework for the 1996-2012 period. The findings indicate that political instability Granger-causes economic development in the short term, while political instability and economic development Granger-cause corruption in the long term. In addition, we employed the forecast error variance decomposition and impulse response function analyses to investigate the dynamic interaction between the variables. The results demonstrate positive unidirectional Granger causality from political instability to economic development in the short term and positive unidirectional Granger causality from political instability and economic development to corruption in the long term in ECOWAS countries. Thus, ECOWAS governments should employ policies to promote political stability in the region.

KEY WORDS: $\quad$ Corruption, Political instability, Economic development, ECOWAS

JEL Classification: E21

'Othman Yeop Abdullah Graduate School of Business, Univeristi Utara Malaysia, 06010 Sintok, Kedah, Malaysia; ${ }^{2}$ School of Economics, Finance and Banking, Univeristi Utara Malaysia, 06010 Sintok, Kedah, Malaysia

\section{Introduction}

There is broad consensus that the Economic Community of West African States (ECOWAS) is one of the least developed regions in the world. Furthermore, the region has continued to face rising corruption and

Correspondence concerning this article should be addressed to: Mohd Zaini Abd Karim, Othman Yeop Abdullah Graduate School of Business, Universiti Utara Malaysia, 06010 Sintok, Kedah, Malaysia. Fax no.: 604-9287160, Tel: 604-9287131. E-mail: agrivetent@gmail.com political instability, which in turn contribute to the region's underdevelopment through adverse effects on government revenue, production, savings, investment, growth, income distribution and poverty (see Aisen \& Veiga, 2013; Asiedu \& Freeman, 2009; Alesina \& Perotti, 1996; Edwards, 1996; Fosu, 1992; Ghura, 2002; Gyimah-Brempong, 2002; Gyimah-Brempong \& Dapaah, 1996; Gyimah-Brempong \& Traynor, 1999; Oto-Peralías, Romero-Ávila, \& Usabiaga, 2013). Although researchers have established that corruption is harmful to an economy (see Gyimah-Brempong, 2002; 
Mauro, 1995), we have observed the coexistence of high levels of corruption and economic development in some Asian countries, such as China. This observation is not surprising, as Leff (1964) and Huntington (1968) suggested that corruption can have positive impact on the economy via increased efficiency in countries where the bureaucracy is inefficient and constitutes a barrier to investment. This statement reflects the "grease the wheels" hypothesis. For instance, entrepreneurs pay bribes to government officials (grease the wheels) to reduce the time that they spend in queues to obtain business permits, licenses or contract approval. This system in turn increases efficiency and investment and, as a result, economic growth (Méon \& Sekkat, 2005). In addition, Goldsmith (1999) cited cases in which entrepreneurs greased the wheels and won contracts even at inflated prices, thus facilitating construction of the intercontinental railway system in the United States.

However, the level of economic development (or income level) plays an important role in promoting or reducing corruption and political instability. Mauro (1995) noted that low-income (less developed) countries tend to be corrupt and politically unstable. Hence, higher-income countries (with improvements in economic conditions) tend to have lesser corruption (Montinola \& Jackman, 2002; Van Rijckeghem \& Weder, 2001; Schumacher, 2013) and higher political stability (Adelman \& Morris, 1968; Helliwell, 1994). Corruption and political instability, including economic development, seem to reinforce one another, at least in the ECOWAS region. Whereas the military allude to corruption and poor economic conditions, among other things, for seizing power or staging a coup, it has also been accused of engaging in massive corruption and failing to bring the majority of citizens out of poverty (Edi, 2006). Moreover, some scholars hold the view that corruption is an important determinant of political instability (Mauro, 2004; Mbaku \& Paul, 1989). Other authors claim that political instability accounts for the high level corruption found in many countries (Billger \& Goel, 2009; Campbell \& Saha, 2013; Park, 2003; Serra, 2006; Shabbir \& Anwar, 2007; Zhang, Cao, \& Vaughn, 2009) and that political stability tends to moderate the adverse effects of corruption in an economy (Habib \& Zurawicki, 2001).
The various reports of Transparency International (TI), which publishes the corruption perception index (CPI), suggest that most ECOWAS countries are highly corrupt. Of the 15 countries in the ECOWAS region, only Cape Verde is among the top 50 in the TI ranking in the past few years. Similarly, the Political Risk Service International Country Risk Guide (ICRG) political risk rating, which reflects the extent of political uncertainty, demonstrates that ECOWAS countries are politically unstable. Many ECOWAS countries have had an average rating of less than $60 \%$ for several years, indicating that they have been experiencing serious political problems.

Despite the abundant research on economic development, corruption and political instability, few attempts have been made to examine whether there is a causal relationship among them. Most studies have focused on the relationship between two of the variables, while studies examining the association among the three variables are almost non-existent. For instance, researchers have investigated the causal effects of the relationships between corruption and development/growth (Bentzen, 2012; Blackburn \& ForguesPuccio, 2007; Gyimah-Brempong, 2002; Mauro, 1995; Ugur \& Dasgupta, 2011), political instability and development/growth (Aisen \& Veiga, 2013; Alesina et al., 1996; Comeau, 2003; Fosu, 2002a, 2002b; Mbaku, 1988), and corruption and political conditions (Mbaku \& Paul, 1989; Montinola \& Jackman, 2002). To our knowledge, this work is the first attempt to investigate the causal relationship among corruption, political instability, and economic development within a multivariate cointegration and error-correction framework in ECOWAS countries. An investigation of the causal relationship between corruption/political instability and economic development, for instance, is highly important because it provides useful information on which variables governments should emphasize. If the results of the causality test reveal that corruption causes political instability, then authorities can employ measures to reduce corruption to attain higher political stability. However, if the results indicate that it is political instability that precedes corruption, then governments can design policies to promote political stability with the goal of making society corruptionfree. Similarly, if the causality test suggests that economic development causes corruption and/or political 

Table 1. A Summary of the Literature on Corruption, Political Instability and Economic Development

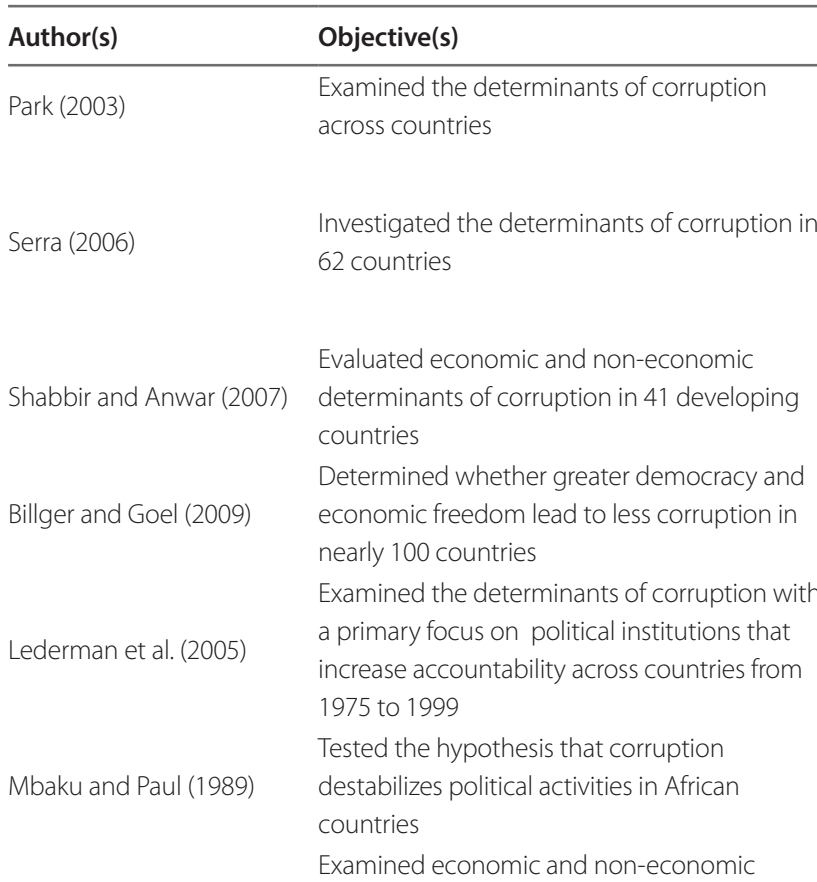

Bollen and Jackman (1985) determinants of political democracy in a sample of almost 100 countries

\section{Empirical evidence}

Socio-political stability leads to lower corruption

Higher levels of political instability are associated with higher corruption, while the length of preservation of democratic institutions has a negative relationship with corruption

The level of economic development has a negative effect on corruption

Greater democracy reduces corruption

Democracies along with parliamentary systems, political stability, and freedom of press are negatively related to corruption

Corruption leads to the destabilization of political activities

Economic development was significant in all regression analyses

Analyzed the relationship among democracy, political instability and economic growth in a sample of 120 countries

Gyimah-Brempong and

Traynor (1999)

Gyimah-Brempong (2002)

Ugur and Dasgupta (2011)

Explored the relationship between political instability and economic growth in SSA Evaluated the impact of corruption on

Growth in income per capita has a positive impact on democracy, but the effect on political violence is negative

Higher economic growth leads to lesser political instability

Corruption decreases economic growth directly and indirectly via reduced investment in physical capital

Corruption has a negative effect on per capita GDP growth.

Corruption reduces economic growth directly by slowing productivity and indirectly by lowering investment

Higher political instability leads to lower GDP per capita growth rates via its effect on productivity growth as well as physical and human capital accumulation Corruption has a significant negative Investigated the impact of corruption in a relationship with economic development sample of 48 SSA countries from 1996 to 20 avaluated the factors responsible for high corruption in Italy during the 1963-2001 period

Level of economic development has a significant impact on corruption

Estimated the relationship between economic growth and five measures of democracy in 100 countries from 1970 to 1999
Democratic countries have higher growth rates
Butkiewicz and Yanikkaya (2006) 
Table 1. A Summary of the Literature on Corruption, Political Instability and Economic Development (Continued)

\begin{tabular}{|c|c|c|}
\hline Author(s) & Objective(s) & Empirical evidence \\
\hline Fosu (2002) & $\begin{array}{l}\text { Studied the different effects of various elite } \\
\text { political instability situations (which include } \\
\text { coups d'état, abortive coups or coup plots) on } \\
\text { economic growth in } 31 \text { SSA countries from } \\
1960 \text { to } 1986\end{array}$ & $\begin{array}{l}\text { Abortive coups and coup plots rather than } \\
\text { successful coups have a negative effect on } \\
\text { economic growth }\end{array}$ \\
\hline Mbaku (1988) & $\begin{array}{l}\text { Examined the impact of political instability on } \\
\text { economic development in SSA countries }\end{array}$ & $\begin{array}{l}\text { Lack of political stability has negatively } \\
\text { impacted economic performance }\end{array}$ \\
\hline Ades and Chua (1997) & $\begin{array}{l}\text { Evaluated the effect of regional instability on } \\
\text { economic growth in } 98 \text { countries from } 1960 \\
\text { to } 1985\end{array}$ & $\begin{array}{l}\text { Existence of negative spillovers in politically } \\
\text { unstable neighboring countries }\end{array}$ \\
\hline Alesina et al. (1996) & $\begin{array}{l}\text { Investigated the relationship between political } \\
\text { instability and GDP per capita growth in a } \\
\text { sample of } 113 \text { countries from } 1950 \text { to } 1982\end{array}$ & $\begin{array}{l}\text { Growth tends to be lower in countries } \\
\text { and periods with a strong tendency for } \\
\text { government collapse }\end{array}$ \\
\hline
\end{tabular}

of corruption on economic growth include the works of Mo (2001), Anoruo and Braha (2005), and Farooq et al. (2013). Similarly, others have confirmed a negative association between corruption and economic development (Bentzen, 2012; Blackburn \& Forgues-Puccio, 2007; Okafor, Smith, \& Ujah, 2014).

Some researchers have also found a negative effect of political instability on growth (see Asteriou \& Price, 2001; Comeau, 2003; Devereux \& Wen, 1998; Butkiewicz \& Yanikkaya, 2006). For example, Devereux and Wen (1998) developed a simple model that relates political instability to the share of government spending in GDP and economic growth for a group of 52 countries during the 1960-1985 period. The authors discovered that political instability dampens economic growth but increases the share of government spending in GDP. Asteriou and Price (2001) employed GARCH-M models to examine the effect of political instability on economic growth in the United Kingdom from 1961 to 1997 . The authors found a strong negative effect of political instability on growth. Comeau (2003) tested the hypothesis that socio-political instability has a negative effect on growth in a group of countries selected from the Latin American and East Asian regions. The author discovered that sociopolitical instability has a negative impact on growth. Butkiewicz and Yanikkaya (2006) estimated the relationship between economic growth and five measures of democracy using panel data for 100 countries dur- ing the 1970-1999 period. The results suggested that democratic countries have higher growth rates.

Many studies have found that political instability has a negative effect on economic growth (see Ades \& Chua, 1997; Aisen \& Veiga, 2013; Alesina et al., 1996; Asteriou \& Siriopoulos, 2000; Campos \& Karanasos, 2008; Fosu, 2002; Mbaku, 1988). However, Butkiewicz and Yanikkaya (2005) found a weak relationship between socio-political instability and economic growth. The authors also discovered that the impact of sociopolitical instability is higher in more developed and highly democratic states. A summary of the literature review is presented in table 1.

The literature review clearly indicates that researchers have not paid adequate attention to the issue of causality among corruption, political instability and economic development. Thus, this paper attempts to contribute to the literature by investigating the causal relationship among the variables in ECOWAS countries.

\section{Theoretical framework and model}

Scholars have made attempts to theoretically establish a link among corruption, political instability, and economic development. In explaining the connection between corruption, political instability and economic growth, for instance, Mauro (2000) described a scenario in which an individual politician sets a high bribe rate. The attendant widespread corruption will 
have adverse effects on economic performance (that is, sluggish economic growth), leading to the collapse of the government. For example, corruption among government officials or bureaucrats reduces the amount of social services such as healthcare and education that alleviate poverty and inequality (Gupta, Davoodi, \& Alonso-Terme, 2002) and therefore leads to social discontent, protests, strikes, and political violence. Sustained dissatisfaction among citizens will lead to a collapse of (or a change in) government. In developed countries, a change in government occurs through the electioneering process (Gyimah-Brempong \& Dapaah, 1996) and in line with constitutional provisions. By contrast, in developing countries such as those in the ECOWAS, an unconstitutional change in government through military intervention has always been the case. Military takeover in the ECOWAS region appears to be the norm rather than exception (Edi, 2006), and it tends to have a destabilizing impact on political stability in these countries because of their fragile political structures (Adelman \& Morris, 1968).

Moreover, frequent changes in government induce public or elected officials to practice rent-seeking behavior because of the high uncertainty surrounding their tenure of office. In a previous study, Shleifer and Vishny (1993) cited in Park (2003) argued that if public officials realize that their term in office will be shortlived because of political instability, they will become irresponsible and become involved in rent-seeking behavior. Using the same line of argument, Park (2003) opined that high uncertainty and anxiety among public officials (arising from political instability) would lead them to seek gain through corrupt means to protect their social status even after they no longer have their positions. Moreover, in explaining Lipset and Raab's (1970) concept of "status strain", Park (2003) emphasized that the fear of a decline in status will compel people to do anything (including engage in corrupt behaviors) to maintain their status and property.

Economic development (or income level) largely promotes or reduces corruption and political instability in a country. Mauro (1995) proposed that low-income countries are likely to be corrupt and politically unstable. In fact, low income levels or civil servant wages encourage rent-seeking behavior because people see corruption as an opportunity to improve their socio-economic well-being. By contrast, an improvement in economic conditions (such as higher wages or income) tends to lower corruption (Montinola \& Jackman, 2002; Van Rijckeghem \& Weder, 2001; Schumacher, 2013). Similarly, declining economic fortunes encourages discontent and socio-political instability. However, higher economic development, such as higher incomes, improves people's well-being and promotes political stability (Adelman \& Morris, 1968; Helliwell, 1994).

Meanwhile, economic development can be influenced by the level of corruption and political instability through their negative impact on savings, investment and production, among other effects. For instance, political instability disrupts production activity, reduces investment and negatively influences economic performance (Alesina \& Perotti, 1996; Aisen \& Veiga, 2013; Alesina et al., 1996). According to Butkiewicz and Yanikkaya (2005), one of the best measures to improve the economic well-being of people in the poorest nations is to prevent political instability. In the same vein, corruption discourages investment and production, leading to sluggish growth (Asiedu \& Freeman, 2009; Gyimah-Brempong, 2002; Mauro, 1995). Thus, corruption, political instability and economic development appear to cause each other. Given the issues discussed above, we hypothesize the following:

1: Political instability and economic development do not Granger-cause corruption.

2: Corruption and economic development do not Granger-cause political instability.

3: Corruption and political instability do not Granger-cause economic development.

To estimate the relationship between the variables, we formulate three models in which corruption (COR), political instability (POL) and economic development (PCY) are specified as a function of the other variables. That is,

$$
\begin{aligned}
& C O R_{i t}=\alpha_{0}+\alpha_{1} P O L_{i t}+\alpha_{2} P C Y_{i t}+U_{1 i t} \\
& P O L_{i t}=\beta_{0}+\beta_{1} C O R_{i t}+\beta_{2} P C Y_{i t}+U_{2 i t} \\
& P C Y_{i t}=\delta_{0}+\delta_{1} C O R_{i t}+\delta_{2} P O L_{i t}+U_{3 i t}
\end{aligned}
$$



Table 2. Panel Unit Root Test Results for the Variables

\begin{tabular}{lcccc}
\hline \multirow{2}{*}{ Variables } & \multicolumn{2}{c}{ Fisher-ADF } & \multicolumn{2}{c}{ Fisher Phillips-Perron } \\
\cline { 2 - 5 } & Level & First difference & Level & First difference \\
\hline \multirow{2}{*}{ POL } & -1.0684 & $-7.1952^{* * *}$ & -2.0456 & $-10.3496^{* * *}$ \\
& $(0.1427)$ & $(0.0000)$ & $(0.2004)$ & $(0.0000)$ \\
COR & 3.6992 & $-5.6420^{* * *}$ & 4.8088 & $-6.2817^{* * *}$ \\
& $(0.9999)$ & $(0.0697)$ & $(1.0000)$ & $(0.0000)$ \\
PCY & 5.9814 & $-5.7279^{* * *}$ & 7.9195 & $-2.9273^{* * *}$ \\
& $(1.0000)$ & $(0.0000)$ & $(1.0000)$ & $(0.0017)$ \\
\hline
\end{tabular}

Note: POL refers to political instability, COR refers to corruption, and PCY refers to economic development. The numbers in parentheses are probability values. ${ }^{* *}$ indicate a rejection of the null hypothesis of the unit root at the $1 \%$ significance level.

Economic development is captured by income (GDP) per capita. Studies have used income per capita as a proxy for economic development (see Bentzen, 2012; Bollen \& Jackman, 1985). Data on GDP per capita were obtained from the WDI. This paper considers ECOWAS countries (excluding Cape Verde and Benin because of unavailable data on political instability) and covers the 1996-2012 period. Although Benin and Cape Verde are not included in our analysis, their exclusion may not have had any serious effects on the results. For instance, countries with similar characteristics (such as the level of development) are considered in our analysis. Cape Verde has the highest GDP per capita $(\$ 4,000)$ in the ECOWAS region, followed by Ghana $(\$ 3,300)$ and Nigeria $(2,700)$, which are included in the analysis. Similarly, Cote D'Ivoire $(\$ 1,700)$ has almost the same GDP per capita as Benin $(\$ 1,600)$.

\section{Results}

Having specified the respective models, we conducted a unit root test to ascertain whether the series used in this study are stationary. Standard economic theory requires series to be stationary prior to estimating their relationship to avoid generating spurious results. Fisher augmented Dickey-Fuller (Fisher-ADF) and Fisher PhillipsPerron (Fisher-PP) statistics were employed to test the unit root properties of the series. The results of the unit root test are presented in table 2 .

The table clearly indicates that the series have a unit root at level but are stationary at the first difference. This outcome supports the claim that many macroeconomic variables are non-stationary at level but stationary after the first difference (Nelson \& Plosser, 1982). Our next task is to investigate if there is a long-term equilibrium relationship (cointegration) between the series using the Pedroni residual cointegration test (Pedroni, 1999). The Pedroni statistics tests (seven of them) were used to investigate whether the error process of the estimated equation is stationary and to test the null hypothesis of no cointegration against the alternative of cointegration. The first four statistics test the null hypothesis of no cointegration for all cross-sectional units (within a dimension), while the other three statistics test the null hypothesis of no cointegration based on pooling between dimensions. The existence of cointegration suggests that the estimated relationship is not spurious. In addition, if the tests reveal the presence of cointegration, then causality will exist in at least one direction (Granger, 1986). The results of the cointegration test are presented in table 3.

Given that the variables are cointegrated, we took another step to determine the direction of causality between them. Granger (1969) proposed that variable X is said to "Granger cause" variable Y if and only if Y is better predicted by past values of $\mathrm{X}$ than by using past values of $\mathrm{Y}$ in either case. In other words, if X helps in forecasting Y, we can conclude that X Granger-causes Y. Thus, our main objective here is to examine whether current values of the individual dependent varble can be predicted by past values of the explanatory variables. To employ the Granger causality test for the variables, we estimated the following multivariate vector error-correction models (VECM):

$$
\begin{aligned}
& \Delta C O R_{i t}=\alpha_{0}+\sum_{j=1}^{J} \alpha_{1} \Delta P O L_{i t-j}+\sum_{j=1}^{J} \alpha_{2} \Delta P C Y_{i t-j}+ \\
& +\sum_{j=1}^{J} \alpha_{3} \Delta C O R_{i t-j}+\phi_{1} E C T_{t-1}+U_{4 i t}
\end{aligned}
$$


Table 3. Results of the Pedroni Residual Cointegration Test

\begin{tabular}{ll}
\hline Statistics (Within dimension) & Value \\
\hline Panel v-statistic & -1.2027 \\
Panel rho-statistic & 2.5870 \\
Panel PP-statistic & $-2.2122^{* *}$ \\
Panel ADF-statistic & $-1.7342^{* *}$ \\
\hline & \\
\hline Statistics (Between dimensions) & Value \\
\hline Group rho-statistic & 3.5304 \\
Group PP-statistic & $-4.2650^{* * *}$ \\
Group ADF-statistic & $-2.2412^{* *}$ \\
\hline
\end{tabular}

Note: POL refers to political instability, COR refers to corruption, and PCY refers to economic development. ** and *** indicate a rejection of the null hypothesis of no cointegration at the $5 \%$ and $1 \%$ significance levels, respectively.

Table 4. Results of Granger Causality Test

\begin{tabular}{lcccc}
\hline Dependent variable & $\Delta$ COR $_{t}$ & $\Delta$ OOL $_{t}$ & $\Delta \mathbf{P C Y}_{\mathbf{t}}$ & ECT $_{\mathrm{t}-1}$ \\
\hline$\Delta \mathrm{COR}_{\text {it }}$ & - & 1.6508 & 2.5074 & $-0.1882^{* *}$ \\
$\Delta \mathrm{POL}_{\text {it }}$ & 0.3609 & - & 0.0411 & -0.0580 \\
$\Delta \mathrm{PCY}_{\text {it }}$ & 0.0197 & $11.2356^{* * *}$ & - & -0.0243 \\
\hline
\end{tabular}

Note: ${ }^{* *}$ and ${ }^{* * *}$ indicate a rejection of the null hypothesis of no Granger causality at the $5 \%$ and $1 \%$ significance levels, respectively.

$$
\begin{aligned}
& \triangle P O L_{i t}=\beta_{0}+\sum_{j=1}^{J} \beta_{1} \Delta C O R_{i t-j}+\sum_{j=1}^{J} \beta_{2} \Delta P C Y_{i t-j}+ \\
& +\sum_{j=1}^{J} \beta_{3} \Delta P O L_{i t-j}+\phi_{2} E C T_{t-1}+U_{5 i t} \\
& \Delta P C Y_{i t}=\delta_{0}+\sum_{j=1}^{J} \delta_{1} \Delta C O R_{i t-j}+\sum_{j=1}^{J} \delta_{2} \Delta P O L_{i t-j}+ \\
& +\sum_{j=1}^{J} \delta_{3} \Delta P C Y_{i t-j}+\phi_{3} E C T_{t-1}+U_{6 i t}
\end{aligned}
$$

Where $C O R_{i t}$ and $C O R_{i t-j}$ represent the current and lagged values of corruption, $P O L_{i t}$ and $P O L_{i t-j}$ are the current and lagged values of political instability, and $P C Y_{i t}$ and $P C Y_{i t-j}$ are the current and lagged values of the level of economic development, respectively. Additionally, $\Delta$ is the first-difference opera- tor, and $U_{i t}$ are the residuals. Moreover, $E C T_{t-1}$ is the one period lag of the error-correction term, and the statistical significance of the $E C T_{t-1}$ is used to determine the long-term causality.

The results of the Granger causality tests reported in table 4 indicate that there is short-term unidirectional causality from political instability to economic development, while there is long-term unidirectional causality from political instability and economic development to corruption. This result implies that political instability Granger-causes economic development in the short term and that both economic development and political instability Granger-cause corruption in the long term in ECOWAS countries. 


\section{Forecast Error Variance Decomposition Analysis}

The Granger causality analysis conducted above is limited to the 1996-2012 period, but it does not consider the dynamic interaction of the variables beyond that period. In an attempt to understand the dynamic relationship among corruption, political instability and economic development outside of the sample period of 1996-2012, we performed a forecast error variance decomposition analysis (FEVD) (Sims, 1980). The FEVD is useful in assessing the amount of variation in a variable caused by its own shock and by shocks to other variables. In the short term, a larger percentage of the variation in a variable results from its own shock, while in the long term, the impact of shocks on other variables increases. Each of the variables in the system is disturbed by one standard deviation.

The results of the variance analysis presented in table 5 indicate that corruption is the most exogenous variable, followed by political instability and economic development. In the second year, for instance, $98.53 \%$, $98.47 \%$ and $98.04 \%$ of the variations in the forecast error variance for corruption, political instability and economic development, respectively, is explained by its own shock. In explaining the shocks to corruption, political instability is more important than economic development in both the short and long term. Specifically, political instability explains $1.00 \%$ of the variations in corruption, while economic development accounts for $0.46 \%$ of the variations in corruption in the second year. Moreover, political instability explains $7.97 \%$ and $17.73 \%$ of the variations in corruption in the fifth and tenth years compared with the contributions of economic development at $4.53 \%$ and $14.65 \%$ during the same period.

Furthermore, corruption is more important than economic development in explaining shocks to political instability in both the short and long term. In the second year, for instance, $1.43 \%$ of the variation in political instability is explained by corruption, but economic development accounts for $0.10 \%$ of the variation in political instability. Similarly, corruption explains $8.35 \%$ and $20.81 \%$ of the variations in political instability, but the contribution of economic development to variations in political instability is $0.61 \%$ and $1.02 \%$ in the fifth and fifteenth year, respectively. Moreover, corruption is more important than political instability in explaining shocks to economic development in the short and long term. In the second year, for instance, corruption accounts for $1.95 \%$ whereas political instability explains $0.32 \%$ of the variation in economic development. In the same vein, corruption accounts for $0.76 \%$ and $0.55 \%$ of the variation in economic development, while political instability explains $0.27 \%$ and $0.35 \%$ of this variation in the tenth and fifteenth year, respectively.

\section{Impulse Response Function Analysis}

The causality tests conducted earlier provide information only on the direction of causality among the variables; these tests do not indicate whether the sign of the relationship is positive or negative. In addition, causality tests are unable to explain how much time is needed for the impacts to occur in the system. To this end, we conducted impulse response function analysis (IRF) to trace how each variable responded to a shock to the other variables in the system. The IRF results for corruption, political instability and economic development in response to a one-standard-deviation shock in corruption, political instability and economic development over the 15-year period are reported in table 6 .

The results of the IRF reveal that over a period of fifteen years, a one-standard-deviation shock to political instability exerts a positive impact on corruption. A shock to political instability has a positive impact on corruption for the first five years, but between the tenth and fifteenth year, the impact declines but remains near the positive region. Similarly, a shock to economic development has a positive impact on corruption between the first and fifteenth years. Regarding the response of political instability to a shock in corruption and economic development, the results illustrate that a shock to corruption exerts a positive effect on political instability, but the impact declines continuously over the fifteen-year period and remains near the positive region. A shock to economic development has a negative impact on political instability, but the effect decreases over the fifteen-year period. Furthermore, the results demonstrate that a shock to corruption exerts a negative impact on economic development, while a shock to political instability exerts a positive impact on economic development over the fifteen-year period. Although the impact of 
Table 5. Results of the Variance Decomposition Analysis

\begin{tabular}{cccccccccccc}
\hline \multicolumn{3}{c}{ Relative Variance of COR } & \multicolumn{3}{c}{ Relative Variance of POL } & \multicolumn{3}{c}{ Relative Variance of PCY } \\
\hline Years & COR & POL & PCY & Years & COR & POL & PCY & Years & COR & POL & PCY \\
\hline 1 & 100.00 & 0.00 & 0.00 & 1 & 0.03 & 99.97 & 0.00 & 1 & 1.95 & 0.32 & 97.72 \\
2 & 98.53 & 1.00 & 0.46 & 2 & 1.43 & 98.47 & 0.10 & 2 & 1.67 & 0.29 & 98.04 \\
3 & 95.61 & 2.95 & 1.44 & 3 & 3.60 & 96.17 & 0.27 & 3 & 1.46 & 0.26 & 98.28 \\
4 & 91.77 & 5.39 & 2.84 & 4 & 6.00 & 93.55 & 0.45 & 4 & 1.29 & 0.25 & 98.46 \\
5 & 87.50 & 7.97 & 4.53 & 5 & 8.35 & 91.04 & 0.61 & 5 & 1.16 & 0.24 & 98.60 \\
10 & 67.62 & 17.73 & 14.65 & 10 & 16.75 & 82.23 & 1.02 & 10 & 0.76 & 0.27 & 98.97 \\
15 & 53.42 & 21.33 & 25.24 & 15 & 20.81 & 78.17 & 1.02 & 15 & 0.55 & 0.35 & 99.10 \\
\hline
\end{tabular}

Note: Cholesky ordering: COR, POL and PCY

Table 6. Results of the Impulse Response Function Analysis

\begin{tabular}{ccccccccccccc}
\hline & \multicolumn{3}{c}{ Response of COR } & \multicolumn{3}{c}{ Response of POL } & \multicolumn{5}{c}{ Response of PCY } \\
\hline Years & COR & POL & PCY & Years & COR & POL & PCY & Years & COR & POL & PCY \\
\hline 1 & 0.31 & 0.00 & 0.00 & 1 & 0.05 & 2.80 & 0.00 & 1 & -12.90 & 5.23 & 91.33 \\
2 & 0.24 & 0.04 & 0.03 & 2 & 0.44 & 2.44 & -0.12 & 2 & -11.08 & 4.69 & 92.88 \\
3 & 0.19 & 0.06 & 0.05 & 3 & 0.70 & 2.17 & -0.19 & 3 & -9.78 & 4.48 & 94.65 \\
4 & 0.15 & 0.08 & 0.06 & 4 & 0.86 & 1.96 & -0.24 & 4 & -8.84 & 4.49 & 96.60 \\
5 & 0.13 & 0.09 & 0.07 & 5 & 0.96 & 1.81 & -0.25 & 5 & -8.14 & 4.67 & 98.70 \\
10 & 0.08 & 0.10 & 011 & 10 & 1.00 & 1.36 & -0.21 & 10 & -6.46 & 6.60 & 110.70 \\
15 & 0.06 & 0.09 & 0.14 & 15 & 0.86 & 1.12 & -1.11 & 15 & -5.77 & 9.07 & 124.75 \\
\hline
\end{tabular}

Note: Cholesky ordering: COR, POL and PCY

political instability fell between the first and second years, it shows a rising trend from the third to fifteenth years.

In sum, the empirical results indicate that there is positive causality running from political instability to economic development in the short term and from political instability and economic development to corruption in the long term in ECOWAS countries. In separate studies, Fosu (1992, 2001, 2002a, 2002 b) confirmed that political instability is deleterious to economic growth in Sub-Saharan African (SSA) countries. For instance, Fosu (1992) found the adverse impact of political instability in SSA to be almost 33 percent of GDP growth over the 1960-1986 period. Similarly, Fosu (2002b) discovered that political instability adversely affected the transfer of economic growth to human development (measured as a change in an index of life expectancy and literacy) between 1970 and 1985. Many years of political instability (military intervention in politics) have contributed to the poor economic performance of ECOWAS countries such as Nigeria. Between 1960 and 1995, Nigeria failed to make any meaningful economic progress (given its potential) because of numerous military takeovers. In addition to military coups, conflicts caused primarily by armed rebels have been on the rise since the 1990 s 
in Liberia, Sierra Leone, Guinea-Bissau, Mali, Cote D'Ivoire and, more recently, in Nigeria. Such rising conflict has led to the displacement and destruction of human and physical capital, thus further contributing to the underdevelopment of the region.

Moreover, military rulers in the ECOWAS region have been blamed to a greater extent for the institutionalization of corruption as evident in some countries. The various military regimes alluded to corruption as one of the reasons that they seized power (Edi, 2006). Furthermore, Nigeria's former military rulers have been accused of stealing and mismanaging several billions of dollars belonging to the country. Recently, the Swiss government returned some of the funds alleged to have been looted by the late General Sani Abacha to the Nigerian government. Similarly, General Ibrahim Babangida was accused of mismanaging US $\$ 12$ billion of oil windfalls while he headed the military Junta for 8 years in Nigeria. Moreover, after 15 years of democracy, the political class has also had its fair share of corruption-related activities. Many former governors and cabinet members have been investigated for helping themselves to state resources. For instance, a former governor of the oil-rich Delta state in Nigeria (James Ibori) was convicted and consequently sentenced to 13 years in prison by the British government for stealing public funds. In the same vein, high-ranking military officers in Guinea Bissau have been accused of not only legitimizing corruption but they aiding drug trafficking along the shores of their country.

\section{Conclusion and recommendations}

Given that less developed ECOWAS countries are corrupt and politically unstable, it is important to examine the interaction among economic development, corruption and political instability in these countries. This paper examines the causal relationship among corruption, political instability, and economic development in ECOWAS countries within a multivariate cointegration and error-correction framework. The Pedroni cointegration test reveals that the variables are cointegrated, indicating the existence of a long-term equilibrium relationship among corruption, political instability, and economic development. Having confirmed the existence of cointegration, we investigated the direction of causality between the variables using the VECM. The results illustrate that there is short- term unidirectional causality from political instability to economic development, while in the long term, causality runs from economic development and political instability to corruption in ECOWAS countries.

Moreover, we employed the FEVD and IRF to examine the dynamic interaction among corruption, political instability and economic development in ECOWAS outside the sample period of 1996-2012. The FEVD confirmed that corruption, political instability and economic development are endogenous. Political instability is the most important variable accounting for shocks in corruption, while corruption is the most important variable accounting for shocks in political instability and economic development. Furthermore, the IRF illustrated that a shock to political instability and economic development has a positive effect on corruption. Additionally, a shock to corruption has a positive impact on political instability, while a shock to economic development has a negative effect on political instability. In addition, a shock to political instability has a positive effect on economic development, whereas a shock to corruption has a negative impact on economic development. Thus, there is positive unidirectional causality from political instability and economic development to corruption in the long term and positive unidirectional causality from political instability to economic development in the short term in ECOWAS countries.

The findings of this study suggest that years of political instability have contributed to the high rate of corruption and underdevelopment in ECOWAS countries. Researchers have confirmed that corruption increases with political instability (see Lederman et al., 2005; Leite \& Weidmann, 1999; Park, 2003). Likewise, other proxies of political instability have also been found to be correlated with corruption. For instance, it has been observed that democracy (as measured by press freedom) is negatively related to corruption (Brunetti \& Weder, 2003; Lederman et al., 2005). Similarly, improvements in civil liberty reduce corruption (Lederman et al., 2005). In addition, higher levels of decentralization reduce corruption by bringing government closer to the people and ensuring that government officials can be held accountable when the need arises (Fisman \& Gatti, 2002). Furthermore, political instability destroys physical capital and displaces human capital (Le, 2004), disrupts production activ- 
ity (Aisen \& Veiga, 2013), and encourages the violation of property rights, including lack of guarantee for contracts (Svensson, 1998). All of these consequences adversely affect the economy (Aisen \& Veiga, 2013; Alesina et al., 1996).

High levels of corruption and underdevelopment in ECOWAS have been blamed on political instability primarily resulting from many years of military rule (including ethno-religious crises). For instance, Edi (2006) posited that the failure to improve socioeconomic conditions and high corruption, among other factors, led to reoccurring military takeovers in ECOWAS countries. Based on our findings, ECOWAS governments should employ policies to promote political stability to improve economic development and reduce corruption in the region. However, as we stated in the introduction, the use of a single policy option of political stability may not be sufficient to achieve higher levels of economic development and to eliminate corruption from ECOWAS countries.

\section{References}

Abu, N., Karim, M.Z.A., \& Aziz, M.I.A. (2013). Low savings rates in the Economic Community of West African States (ECOWAS): The role of the political instability-income interaction. South East European Journal of Economics and Business, 8 (2), 53-63.

Adelman, I., \& Morris, C. T. (1968). An econometric model of socio-economic and political change in underdeveloped countries. American Economic Review, 58 (5), 1184-1218.

Ades, A., \& Chua, H. B. (1997). Thy neighbor's curse: Regional instability and economic growth. Journal of Economic Growth, 2 (3), 279-304.

Aisen, A., \& Veiga, F. J. (2013). How does political instability affect economic growth?. European Journal of Political Economy, 29, 151-167.

Alesina, A., \& Perotti, R. (1996). Income distribution, political instability and investment. European Economic Review, 40 (6), 1203-1228.

Alesina, A., Ozler, S., Roubini, N., \& Swagel, P. (1996). Political instability and economic growth. Journal of Economic Growth, 1 (2), 189-212.

Anoruo, E., \& Braha, H. (2005). Corruption and economic growth: The African experience. Journal of Sustainable Development in Africa, 7 (1), 43-55.
Asiedu, E. (2006). Foreign direct investment in Africa: The role of natural resources, market size, government policy, institutions and political instability. World Economy, 29 (1), 63-77.

Asiedu, E., \& Freeman, J. (2009). The effect of corruption on investment growth: Evidence from firms in Latin America, Sub-Saharan Africa, and transition countries, Review of Development Economics, 13 (2), 200-214.

Asteriou, D., \& Price, S. (2001). Political instability and economic growth: UK time series evidence. Scottish Journal of Political Economy, 48 (4), 383-399.

Asteriou, D., \& Siriopoulos, C. (2000). The role of political instability in stock market development and economic growth: The case of Greece. Economic Notes, 29 (3), 355-374.

Bentzen, J. S. (2012). How bad is corruption? Crosscountry evidence of the impact of corruption on economic prosperity. Review of Development Economics, 16 (1), 167-184.

Billger, S. M., \& Goel, R. K. (2009). Do existing corruption levels matter in controlling corruption?: Cross-country quantile regression estimates. Journal of Development Economics, 90 (2), 299-305.

Blackburn, K., \& Forgues-Puccio, G. F. (2007). Distribution and development in a model of misgovernance. European Economic Review, 51 (6), 15341563.

Bollen, K. A., \& Jackman, R. W. (1985). Economic and noneconomic determinants of political democracy in the 1960s. Research in Political Sociology, 1, 27-48.

Brunetti, A. \& Weder, B. (2003). A free press is bad news for corruption. Journal of Public Economics, 87 (7-8), 1801-1824.

Butkiewicz, J. L., \& Yanikkaya, H. (2005). The impact of sociopolitical instability on economic growth: Analysis and implications. Journal of Policy Modeling 27 (5), 629-645.

Butkiewicz, J. L., \& Yanikkaya, H. (2006). Institutional quality and economic growth: Maintenance of the rule of law or democratic institutions, or both? Economic Modelling, 23 (4), 648-661.

Campbell, N., \& Saha, S. (2013). Corruption, democracy, and Asia-Pacific countries. Journal of the Asia Pacific Economy, 18 (2), 290-303. 
Campos, N. F., \& Karanasos, M. G. (2008). Growth, volatility and political instability: Non-linear time-series evidence for Argentina, 1896-2000. Economics Letters, 100 (1), 135-137.

Claderon, C., \& Chong, A. (2006). Do democracies breed rent-seeking behaviour? Journal of Policy Reform, 9 (4), 247-260.

Comeau, L. (2003). The political economy of growth in Latin America and East Asia: Some empirical evidence. Contemporary Economy Policy, 21 (4), 476-489.

Del Monte, A., \& Papagni, E. (2007). The determinants of corruption in Italy: Regional panel data analysis. European Journal of Political Economy, 23 (2), 379-396.

Devereux, M. B., \& Wen, J. F. (1998). Political instability, capital taxation, and growth. European Economic Review, 42 (9), 1635-1651.

Edi, E. (2006). Pan West Africanism and political instability in West Africa: Perspectives and reflections. The Journal of Pan African Studies, 1 (3), 7-31.

Edwards, S. (1996). Why are Latin America's savings rates so low? An international comparative analysis, Journal of Development Economics, 51 (1), 5-44.

Emerson, P. M. (2006). Corruption, competition and democracy. Journal of Development Economics, 81 (1), 193-212.

Erb, C. B., Harvey, C. R., \& Viskanta, T. E. (1996). Political risk, financial risk and economic risk. Financial Analysts Journal, 52 (6), 29-46.

Farooq, A., Shahbaz, M., Arouri, M., \& Teulon, F. (2013). Does corruption impede economic growth in Pakistan?. Economic Modelling, 35, 622-633.

Fisman, R. \& Gatti, R. (2002). Decentralization and corruption: Evidence across countries. Journal of Public Economics, 83 (3), 325-345.

Fosu, A. K. (1992). Political instability and economic growth: Evidence from Sub-Saharan Africa. Economic Development and Cultural Change, 40 (4), 829-841.

Fosu, A. K. (2001). Political instability and economic growth in developing economies: Some specification empirics. Economics Letters, 70 (2), 289-294.

Fosu, A. K. (2002a). Political instability and economic growth: Implications of coup events in Sub-Saharan Africa. American Journal of Economics and Sociology, 61 (1), 329-348.
Fosu, A. K. (2002b). Transforming economic growth to human development in Sub-Saharan Africa: The role of elite political instability. Oxford Development Studies, 30 (1), 9-19.

Gasiorowski, M. J. (1998). Macroeconomic conditions and political instability: An empirical analysis. Studies in Comparative International Development, 33 (3), 3-17.

Ghura, D. (2002). Tax revenue in Sub-Saharan Africa: Effects of economic policies and corruption. In G. T. Abed, S. Gupta (Eds.), Governance, Corruption, and Economic Performance (pp. 369-395). Washington, DC: International Monetary Fund.

Goldsmith, A. A. (1999). Slapping the grasping hand. American Journal of Economics and Sociology, 58 (4), 865-883.

Granger, C. W. J. (1969). Investigating causal relations by econometric models and cross spectral methods. Econometrica, 37 (3), 424-438.

Granger, C. W. J. (1986). Development in the study of cointegrated economic variables. Oxford Bulletin of Economics and Statistics, 48 (3), 213-228.

Gupta, S., Davoodi, H., \& Alonso-Terme, R. (2002). Does corruption affect income inequality and poverty? Economics of Governance, 3 (1), 23-45.

Gupta, D. K., Madhavan, M. C., \& Blee, A. (1998). Democracy, economic growth and political instability: an integrated perspective. The Journal of SocioEconomics, 27 (5), 587-611.

Gyimah-Brempong, K. (2002). Corruption, economic growth, and income inequality in Africa. Economics of Governance, 3 (3), 183-209.

Gyimah-Brempong, K., \& Dapaah, A. S. (1996). Non elite political instability and economic growth: Evidence from Sub-Saharan Africa. Journal of Economic Development, 21 (1), 181-210.

Gyimah-Brempong, K. \& Traynor, T. L. (1999). Political instability, investment and economic growth in Sub-Saharan Africa. Journal of African Economies, 8 (1), 52-86.

Habib, M., \& Zurawicki, L. (2001).Country-level investments and the effect of corruption-Some empirical evidence. International Business Review, 10 (6), 687-700.

Hayakawa, K., Kimura, F., \& Lee, H. H. (2013). How does country risk matter for foreign direct in- 
vestment? The Developing Economies, 5 (1), 60-78.

Heaney, R., \& Hooper, V. (1999). World, regional and political risk influences upon Asia Pacific equity market returns. Australian Journal of Management, 24 (2), 131-142.

Helliwell, J. F. (1994). Empirical linkages between democracy and economic growth. British Journal of Political Science, 24 (2), 225-248.

Huntington, S. P. (1968). Political order in changing societies. New Haven, CT: Yale University Press.

Iwasaki, I., \& Suzuki, T. (2012). The determinants of corruption in transition economies. Economics Letters, 114 (1), 54-60.

Lambsdorff, J. G. (1999, October). The Transparency International corruption perceptions index 1999: Framework document. Transparency International, Berlin. Retrieved from http://www.icgg.org/ downloads/1999_CPI_FD.pdf

Lambsdorff, J. G. (2006). The validity and precision of subjective indicators (CPI). In C. Sampford, A. Shacklock, C. Connors, \& F. Galtung (Eds.), Measuring Corruption (pp. 81-99). Aldershot, UK: Ashgate Publishing Company.

Le, Q. V. (2004). Political and economic determinants of private investment. Journal of International Development, 16 (4), 589-604.

Lederman, D., Loayza, N. V., \& Soares, R. R (2005). Accountability and corruption: Political institutions matter. Economics \& Politics, 17 (1), 1-35.

Leff, N. H. (1964). Economic development through bureaucratic corruption. American Behavioral Scientist, 8 (3), 8-14.

Leite, C. A. \& Weidmann, J. (1999). Does mother nature corrupt?: Natural resources, corruption, and economic growth (Working Paper No. 99/85). International Monetary Fund.

Linder, A., \& Santiso, C. (2002). Assessing the predictive power of country risk ratings and governance indicators (Working Paper No. 0202). School of Advanced International Studies. The Johns Hopkins University.

Lipset, S. M., \& Raab, E. (1970). The politics of unreason: Right-wing extremism in America, 1790-1970. New York, NY: Harper \& Row.

Mauro, P. (1995). Corruption and growth. Quarterly Journal of Economics, 110 (3), 681-712.
Mauro, P. (2004). The persistence of corruption and slow economic growth. International Monetary Fund Staff Papers, 51 (1), 1-18.

Mbaku, J. M. (1988). Political instability and economic development in Sub-Saharan Africa:

Some recent evidence. Review of Black Political Econo$m y, 17$ (1), 89-111.

Mbaku, J. M., \& Paul, C. (1989). Political instability in Africa: A rent-seeking approach. Public Choice Public Choice, 63 (1), 63-72.

Méon, P. G., \& Sekkat, K. (2005). Does corruption grease or sand the wheels of growth? Public Choice, 122 (1-2), 69-97.

Mo, P. H. (2001). Corruption and economic growth. Journal of Comparative Economics, 29 (1), 66-79.

Montinola, G. A., \& Jackman, R.W. (2002). Sources of corruption: A cross-country study. British Journal of Political Science, 32 (1), 147-170.

Nelson, C. R., \& Plosser, C. I. (1982). Trends and random walks in macroeconomic time series: Some evidence and implications. Journal of Monetary Economics, 10 (2), 139-162.

Okafor, C. E., Smith, M., \& Ujah, N. (2014). Kleptocracy, nepotism, kakistrocracy: Impact of corruption in Sub-Saharan African countries. International Journal of Economics and Accounting, 5 (2), 97-115.

Oto-Peralías, D., Romero-Ávila, D., \& Usabiaga, C. (2013). Does fiscal decentralization mitigate the adverse effects of corruption on public deficits? European Journal of Political Economy, 32, 205231.

Park, H. (2003). Determinants of corruption: A crossnational analysis. Multinational Business Review, 11 (2), 29-48.

Pedroni, P. (1999). Critical values for cointegration tests in heterogeneous panels with multiple regressors. Oxford Bulletin of Economics and Statistics, 61, 653-670.

Serra, D. (2006). Empirical determinants of corruption: A sensitivity analysis. Public Choice, 126 (1), 225-256.

Schumacher, I. (2013). Political stability, corruption and trust in politicians. Economic Modelling, 31, 359-369.

Shabbir, G., \& Anwar, M. (2007). Determinants of corruption in developing countries. The Pakistan Development Review, 46 (4), 751-764. 
Shleifer, A., \& Vishny, R. (1993). Corruption. Quarterly Journal of Economics, 108 (3), 599-617.

Sims, C. A. (1980). Macroeconomics and Reality. Econometrica, 48 (1), 1-48.

Svensson, J. (1998). Investment, property rights and political instability: Theory and evidence. European Economic Review, 42 (7), 1317-1341.

Swaleheen, M. (2007). Corruption and investment choices: A panel data study. Kyklos, 60 (4), 601616.

Ugur, M., \& Dasgupta, N. (2011). Corruption and economic growth: A meta-analysis of the evidence on low-income countries and beyond (MPRA 31226). University Library of Munich, Germany.

Van Rijckeghem, C., \& Weder, B. (2001). Bureaucratic corruption and the rate of temptation: Do wages in the civil service affect corruption, and by how much? Journal of Development Economics, 65 (2), 307-331.

Williams, A., \& Siddique, A. (2008). The use (and abuse) of governance indicators in economics: A review. Economics of Governance, 9 (2), 131-175.

Zhang, Y., Cao, L., \& Vaughn, M. S. (2009). Social support and corruption: Structural determinants of corruption in the world. Australian \& New Zealand Journal of Criminology, 42 (2), 204-217. 